PERSPEKTIF, 9 (2) (2020): 439-446

DOI: https://doi.org/10.31289/perspektif.v9i2.3942

PERSPEKTIF

Available online http://ojs.uma.ac.id/index.php/perspektif

\title{
Peranan Dana Desa dalam Pengembangan Indeks Desa Membangun di Kecamatan Sibolangit Kabupaten Deli Serdang Provinsi Sumatera Utara
}

\author{
The Role of Village Funds in Developing Village Index \\ Building in Sibolangit Sub-District, Deli Serdang Regency, \\ North Sumatra Province
}

\author{
Beni Haryanto Tambunan*, Marlon Sihombing \& R. Hamdani Harahap \\ Program Studi Pembangunan, Universitas Sumatera Utara, Indonesia
}

Diterima: 24 Juni 2020; Disetujui: 13 Mei 2020; Dipublish: 18 Juli 2020

\begin{abstract}
Abstrak
Penelitian ini bertujuan untuk mendeskripsikan peranan dana desa dalam pengembangan Indeks Desa Membangun.. Metode penelitian dilakukan dengan pendekatan kualitatif, informan dalam penelitian ini adalah informan kunci, informan utama dan informan tambahan. Lokasi penelitian dilakukan di kecamatan sibolangit dengan 5 desa sampel, yang terdiri dari 2 desa tertinggal, 2 desa berkembang, dan 1 desa maju. Hasil penelitian ini menggambarkan bagaimana desa sebelum adanya dana desa dan setelah adanya dana desa, kemudian peranan dana desa terhadap pengembangan indeks desa membangun dimana dalam indeks desa membangun ini banyak indikator dan sub indikator penilaiannya, serta melihat faktor penghambat desa sulit berkembang.. Kesimpulan dari penelitian ini adalah desa masih sulit mengembangkan daerahnya walaupun ada dana desa.
\end{abstract}

Kata Kunci: Dana Desa, Pengembangan, Indeks Desa Membangun.

Abstract
This study aims to describe the role of village funds in the development of the Village Development Index. The research method was conducted with a qualitative approach, the informants in this study were key informants, key informants and additional informants. The research location was conducted in Sibolangit sub-district with 5 sample villages, consisting of 2 disadvantaged villages, 2 developing villages, and 1 developed village. The results of this study illustrate how the village before the existence of village funds and after the existence of village funds, then the role of village funds in the development of the village index build in which in the village index builds a lot of indicators and sub-indicators of its assessment, as well as looking at factors hampering the village difficult to develop. this is a village that is still difficult to develop its area despite village funds.

Keywords: Village Funds, Development, Village Development Index.

How to Cite: Tambunan, H.T Sihombing, M. \& Hamdani, R. (2020). Peranan Dana Desa Dalam Pengembangan Indeks Desa Membangun di Kecamatan Sibolangit Kabupaten Deli Serdang Provinsi Sumatera Utara. PERSPEKTIF, 9(2): 438-446

*Corresponding author:

ISSN 2085-0328 (Print)

E-mail: rhamdani@usu.ac.id

ISSN 2684-9305(Online) 


\section{PENDAHULUAN}

Pemerintahan Indonesia saat ini mengalami perubahan dari sentralistik menjadi desentralistik. Istilah Sentralistik sempat populer pada masanya, namun berjalan waktu dan perkembangan zaman sistem ini tidak lagi dapat diterapkan. Permasalahan yang muncul adalah karena dinilai tidak mampu menampung aspirasi atau pendapat daerah-daerah, khususnya yang di daerah terpencil atau terisolir. Untuk menangani permasalahan tersebut, maka yang berperan dalam pemberian pelayanan pada masyarakat adalah pemerintahan desa.

Undang-Undang Nomor 5 Tahun 1979 tentang Pemerintahan Desa, menjelaskan Desa merupakan wilayah yang ditempati oleh sejumlah penduduk sebagai kesatuan masyarakat termasuk di dalamnya kesatuan masyarakat hukum yang mempunyai organisasi pemerintahan terendah langsung di bawah camat dan berhak menyelenggarakan rumah tangganya sendiri dalam ikatan Negara Kesatuan Republik Indonesia. Selain itu UU No. 5 Tahun 1979 ini dianggap sudah tidak layak dan berhak untuk dilakukan pembaharuan, sehubungan dengan perkembangan aman. Untuk mendukung hal tersebut lembaga eksekutif beserta legislatif membuat UndangUndang yang mengatur tentang desa, yakni Undang-Undang Nomor 6 Tahun 2014.

Dalam upaya mewujudkan kesejahteraan umum, pemerintah telah menerbitkan Undang-Undang nomor 6 tahun 2014 tentang Desa. Lahirnya undang-undang ini memberikan ruang lebih bagi pemerintahan desa dalam pengambilan keputusan diluar pengaruh negara. Hal tersebut yang menjadi pembeda dengan tata kelola pemeritahan desa sebelumnya. Desa sebagai unit administrasi pemerintahan terkecil memegang peranan penting dan diharapkan menjadi titik awal berkembangnya titik awal pusat-pusat pertumbuhan perekonomian masyarakat. Pembangunan perdesaan dilaksanakan dalam rangka intervensi untuk mengurangi tingkat kesejangan kemajuan antara wilayah perdesaan dan perkotaan sebagai akibat dari pembangunan ekonomi sebelumnya yang cenderung berorientasi pada wilayah perkotaan (Miraza, 2005).

Setiap desa telah menerima dana yang besar mulai dari pemerintah daerah (APBD) maupun dari pemerintah pusat (APBN). Dana
Desa yang diberikan terbagi menjadi 3 (tiga) bagian, yakni Dana Desa yang bersumber dari APBN, Alokasi Dana Desa dan Dana Bagi Hasil Pajak yang bersumber dari APBD. Terkhusus pada Dana Desa dialokasikan dalam Anggaran Pendapatan dan Belanja Negara yang diperuntukkan bagi desa yang ditransfer melalui APBD Kabupaten/Kota (Riyadi, 2000). Dana tersebut digunakan untuk membiayai penyelenggaraan pemerintahan, pelaksanaan pembangunan, pembinaan kemasyarakatan, dan pemberdayaan masyarakat (Jamaluddin, et. Al., 2018). Besarnya anggaran yang dikelola oleh desa ini, membuat pemerintah pusat perlu membuat suatu pengukuran. Sehingga dikeluarkanlah Permendesa PDTTrans Nomor 2 Tahun 2016 tentang Indeks Desa Memangun (IDM) ada 3 unsur yang menjadi tolok ukur IDM yakni Ketahanan Sosial, Ketahanan Ekonomi, dan Ketahanan Ekologi (Peraturan Menteri Keuangan Republik Indonesia Nomor 50/PMK.07/2017 tentang Pengelolalaan Transfer ke Daerah dan Dana Desa).

Kecamatan Sibolangit merupakan wilayah yang berada di Kabupaten Deli Serdang, Sumatera Utara. Wilayah ini merupakan kecamatan yang memiliki sebanyak 30 desa. Beberapa Desa di Kecamatan Sibolangit masih belum memiliki ketahanan sosial yang cukup baik. Jarak tempuh ke puskesmas terdekat bisa mencapai 1,5 jam atau lebih. Selain itu, tenaga kesehatan seperti bidan dan perawat juga masih belum memadai. Akses menuju sarana kesehatan yang kurang mendukung, selain jarak antar dusun cukup jauh dan desa yang berada di dataran tinggi menjadi kendalanya. Beberapa desa masih belum terfasilitasi di bidang pendidikan. Jumlah sekolah di setiap desa, bahkan ada desa yang tidak memiliki sekolah dasar menyebabkan anak-anak sekolah dengan jarak tempuh yang cukup jauh. Bahkan ada pula anak desa yang tinggal indekos dan menginap di rumah teman atau keluarga yang dekat dengan sekolah.

Ketahanan Ekonomi di mana desa memiliki tempat perdagangan atau koperasi. Namun, masih belum ada pusat pelayanan perdagangan di setiap desa yang membuat Kecamatan Sibolangit sulit meningkatkan perekonomian. Bahkan hal tersebut diperparah dengan sulitnya moda transportasi publik, dikarenakan angkutan umum hanya ada sekali sehari. Beberapa desa bahkan 
terdapat angkutan yang kurang layak dan ojek motor sulit untuk didapat, itu pun dengan ongkos yang mahal. Kualitas jalan yang ada di desa-desa juga masih banyak yang belum layak. Aspal yang rusak dan berkerikil serta jalan yang tidak begitu lebar. Hal ini diperparah dengan kondisi jalan memiliki tingkat kesulitan yang tinggi, sebab di kirikanan terdapat jurang.

Ketahanan Ekologi desa-desa di Kecamatan Sibolangit merupakan wilayah yang rawan akan bencana alam. Dalam kurun waktu kurang lebih 6 tahun terakhir sudah dua kali terjadi banjir bandang. Terakhir terjadi banjir bandang di Desa Martelu pada tahun 2019, walaupun tidak ada korban jiwa namun kerusakan yang ditimbulkan cukup parah. Selain merusak beberapa rumah, banjir ini juga menyebabkan putusnya jalan utama. Dampak sama juga dirasakan desa tetangga, yaitu Desa Ketangkuhen tepatnya Dusun Saringkulit. Banjir membuat jembatan penghubung dusun menuju Desa Sukamaju terputus. Jembatan tersebut merupakan jalan satu-satunya untuk menuju ke desa selanjutnya.

Tahun 2017 merupakan tahun pertama pelaksanaan program Indeks Desa Membangun untuk anggaran tahun 2016. Di kecamatan Sibolangit dari 30 desa yang ada, terdapat 10 desa dengan kategori sangat tertinggal, 16 desa kategori tertinggal, 3 Desa kategori berkembang, dan 1 desa kategori Maju. (Lampiran Menteri Desa, Pembangunan Daerah Tertinggal dan Transmigrasi nomor 030 Tahun 2016). Dari data tersebut kategori sangat dan tertinggal sangat mendominasi. Dengan adanya Dana Desa tentu sangat membantu pengembangan desa-desa tersebut. Namun tidak dengan program IDM, dari data tahun 2018 Kecamatan Sibolangit terdapat perubahan klasifikasi IDM desa yang tidak begitu signifikan, yakni kategori sangat tertinggal menjadi 5, tertinggal menjadi 19, serta berkembang dan maju tetap 1 desa.

Tahun 2019 Indeks Desa Membangun di Kecamatan Sibolangit juga mengalami perubahan. namun tidak pada kategori desa berkembang 5 dan desa maju 1. Perubahan terjadi pada desa sangat tertinggal ke desa tertinggal menjadi 24 desa. Pengembangan data yang cukup lambat ini sebenarnya tidak hanya terjadi di Kecamatan Sibolangit saja. Ini dibuktikan dengan data kecamatan Lubuk
Pakam yang notabene merupakan ibukota kabupaten Deli Serdang. Dimana pada tahun 2016 terdapat 1 desa dengan kategori tertinggal, 5 berkembang dari 6 desa, namun pada tahun 2018 dan 2019 semua desa menjadi berkembang. Ini menjelaskan ada kelambatan perkembangan IDM bukan hanya terjadi pada desa dengan geografis pegunungan saja. Desa yang berada pada Ibukota Kabupaten juga mengalami hal yang sama.

Hal-hal di atas merupakan beberapa masalah yang terjadi di desa-desa Kecamatan Sibolangit terkhusus pada komponenkomponen unsur tolok ukur menurut IDM. Sehingga penulis tertarik untuk melihat Peranan Dana Desa dalam Pengembangan Indeks Desa Membangun di Kecamatan Sibolangit Kabupaten Deli Serdang.

\section{METODE PENELITIAN}

Penelitian ini menggunakan pendekatan deskriptif kualitatif, metode pengumpulan data menggunakan observasi lapangan dan interview. Penelitian ini dilakukan dengan tahapan-tahapan sebagai berikut. Pertama peneliti menentukan desa untuk menjadi sampel atau keterwakilan setiap klasifikasi desa yang ada di kecamatan Sibolangit, selanjutnya peneliti menentukan informan penelitian (informan kunci, informan utama dan informan tambahan) untuk mendapatkan informasi yang lebih akurat dan juga dengan didukung oleh data-data sekunder baik itu dari desa, dan BPS. Teknik analisa data dilakukan dengan cara mereduksi data dari data yang sudah dikumpulkan, menyajikan data, dan verifikasi (Idrus, 2009).

\section{HASIL DAN PEMBAHASAN \\ Desa Sebelum Ada Dana Desa}

Sebelum adanya dana desa, desa sangat bergantung terhadap APBD dalam hal alokasi dana desa. Namun, dana yang ada dinilai sangat kecil untuk menggerakkan roda pemerintahan desa. Bahkan, pekerjaan perangkat desa bukan menjadi pekerjaan yang primadona pada masa itu. Selain itu, desa juga sangat berharap hibah-hibah yang diberikan ke desa. Hal tersebut sejalan dengan hasil wawancara peneliti dengan Kepala Desa Batu Layang yang sudah menjabat dari sebelum adanya Dana Desa dari pemerintah pusat. Berikut petikan wawancaranya: 
"Sebelum adanya Dana Desa dari pemerintah pusat, jelas kami pemerintahan desa sangat sulit untuk berkembang, terutama dalam memberikan pelayanan dan pembangunan didesa. Bahkan kadang kami harus memakai uang sendiri untuk memberikan pelayanan kepada masyarakat, karena gaji kami sebelum ada Dana Desa sangatlah kecil. Apalagi bila dilihat dari beban kerja kami yang begitu berat dulu. Untuk mencari perangkat desa aja dulu sulit, karena gaji yang diterima tidak sebanding."

Selain mewawancarai Kepala Desa Batu Layang, peneliti juga mewawancarai Kepala Desa Suka Makmur. Kepala Desa Suka Makmur juga merupakan kepala desa yang merasakan belum adanya dana desa. Namun desa sukamakmur merupakan satu-satunya desa yang mendapatkan status atau klasifikasi dengan desa maju.

"Dulu sebelum ada Dana Desajelas kami sangat sulit untuk memajukan desa, menjadi perangkatpun masyarakat gak mau. Namun yang membut desa kami masih mendukung dengan adanya bantuan dan investor yang mau menanamkan uangnya untuk memajukan desa, dan membantu membuka lapangan pekerjaan, seperti hotel, villa dan lain sebagainya. Masyarakat saja lebih memilih untuk memilih untuk menjadi pegawai hotel daripada menjadi perangkat desa."

Berdasarkan hasil wawancara dengan beberapa Kepala Desa, bahwa sebelum adanya dana desa, pemerintahan desa sangat sulit mengembangkan potensi yang ada. Bahkan untuk menjadi perangkat desa, masyarakat tidak mau sebab gaji yang kecil. Ini jelas apabila melihat Sibolangit adalah kecamatan yang masyarakat mayoritas mata pencahariaanya sebagai petani dan peternak. Di mana mereka lebih memilih untuk bertani daripada menjadi perangkat desa.

Melihat perkembangan desa yang cukup lambat dan cenderung jalan di tempat, pemerintah mengeluarkan kebijakan untuk memberikan Dana Desa yang cukup besar. Tujuannya agar desa dapat mengembangkan daerahnya secara maksimal. Sehingga diterbitkan UU Nomor 6 Tahun 2014 tentang Desa, di mana di dalam UU ini desa memiliki kewenangan yang cukup luas serta bisa dikatakan bersifat otonomi. Hal ini juga didukung garda terdepan dalam memberikan pelayanan kepada masyarakat. Selain itu, pemerintah juga ingin memberikan pelayanan kepada masyarakat desa melalui Kepala Desa dan perangkatnya. Dalam UU ini juga dijelaskan Dana Desayang berasal dari 3 unsur, yakni DBHP (Dana Bagi Hasil Pajak), ADD (Alokasi Dana Desa), dan DANA DESA (DD). DBHP dan ADD berasal dari alokasi dana APBD, sedangkan Dana Desa berasal dari alokasi dana APBN.

Dengan adanya Dana Desa yang dimulai sejak tahun 2015 hingga saat ini membuat pemerintah mengeluarkan Peraturan untuk mengukur perkembangan desa. Hal tersebut tecantum dalam Permendesa dan PDTTrans Nomor 2 Tahun 2016 tentang Indeks Desa Membangun. Peraturan tersebut dibuat untuk mengukur perkembangan desa yang terbagi dalam 5 klasifikasi, yakni sangat tertinggal, tertinggal, berkembang, maju, dan mandiri. Untuk mengukur hal tersebut pemerintah juga mengeluarkan 3 indikator utama dalam hal mengukur klasifikasi desa yaitu Ketahanan Sosial, Ketahanan Ekonomi, dan Ketahanan Ekologi.

Seperti data yang didapatkan, bahwa Dana Desa yang dianggarkan kepada 5 desa mulai dari tahun 2017 sampai tahun 2020 terus mengalami perubahan. Desa Ujung Deleng dan Desa Batu Layang dengan klasifikasi desa tertinggal. Adapun Dana Desa yang diterima Desa Ujung Deleng sebagai berikut; tahun 2017 sebesar Rp.782.807.000, tahun 2018 sebesar Rp.616.345.000, tahun 2019 sebesar Rp.768.723.000, dan tahun 2020 sebesar Rp.749.116.000. Sedangkan, Dana Desa yang diterima Desa Batu Layang adalah tahun 2017 Rp.755.323.000, tahun 2018 Rp. 667.110.000, tahun 2019 Rp. 770.369.000, dan tahun 2020 Rp.774.704.000.

Untuk desa dengan klasifikasi berkembang adalah Desa Bandar Baru dan Desa Rambung Baru. Adapun Dana Desa yang diterima Desa Bandar Baru sebagai berikut; tahun 2017 sebesar Rp.793.580.000, tahun 2018 Rp.687.681.000, tahun 2019 Rp.775.135.000, dan tahun 2020 Rp.769.439.000. Sedangkan, Dana Desa yang diterima Desa Rambung Baru adalah tahun 2017 Rp.765.379.000, tahun 2018 Rp.680.639.000, tahun 2019 Rp.768.114.000, dan tahun 2020 Rp.761.603.000.

Untuk desa dengan klasifikasi maju adalah Desa Suka Makmur. Adapun Dana Desa yang diterima Desa Suka Makmur sebagai berikut; tahun 2017 Rp.755.335.000, tahun 2018 Rp.649.444.000, tahun 2019 Rp.720.847.000, dan tahun 2020 Rp.707.133.000. 
Dari data di atas, bahwa Dana Desa yang diterima berdasarkan klasifikasi desa mengalami perubahan nominal setiap tahunnya. Dana yang diterima setiap desa bisa dikategorikan cukup besar. Dengan dana tersebut tentunya desa sudah mampu mengembangkan potensi daerahnya masingmasing. Dalam hal ini untuk membiayai pembangunan dan pemberdayaan masyarakat guna meningkatkan kesejahteraan masyarakat desa, kualitas hidup manusia, serta penanggulangan kemiskinan.

\section{Ketahanan Sosial}

Ketahanan sosial merupakan unsur pertama dari penilaian Indeks Desa Membangun. Bisa dikatakan lebih dari sekedar jumlah orang atau individu karena terlibat dalam setiap kegiatan sehari-hari. Dengan demikian, ketahanan sosial merupakan suatu kesanggupan atau kemampuan dalam menghadapi perkembangan yang bergerak secara dinamis. Ketahanan sosial menurut IDM memiliki beberapa dimensi penilaian, yakni kesehatan, pendidikan, modal sosial, dan permukiman.

Kesehatan merupakan indikator pertama dalam penilaian ketahanan sosial. Hal ini dikarenakan kesehatan menjadi salah satu perhatian pemerintah dalam menanggulangi permasalahan kesehatan, terutama masalah stunting. Dalam hal ini yang menjadi indikator adalah pelayanan kesehatan, keberdayaan masyarakat, dan jaminan kesehatan. Dari hasil wawancara, Dana Desa bisa dianggarkan pada beberapa kegiatan untuk mendukung pelayanan kesehatan. Salah satu kegiatannya adalah melakukan pelatihan-pelatihan kesehatan, dalam hal ini fokus pemerintah menghadapi stunting. Dengan adanya dana desa yang diberikan pemerintah pusat, dapat digunakan desa untuk melakukan pelatihan untuk mengatasi stunting. Bahkan dengan adanya dana tersebut, pihak pejabat desa dapat menganggarkan pembelian peralatan kesehatan dalam mendukung kinerja tenaga medis di desa tersebut. Hal ini mulai dilakukan beberapa desa di Kecamatan Sibolangit pada tahun 2019, dengan menganggarkan dana untuk rehabilitasi sarana dan prasarana. Penganggaran seperti Posyandu, penambahan makanan balita dan lansia, serta pemberian insentif kepada kader Posyandu.
Dengan adanya Dana Desa tentunya berdampak kepada pelayanan kesehatan di desa-desa Kecamatan Sibolangit. Desa yang termasuk dalam klasifikasi tertinggal, terdapat perbedaan dalam pelayanan kesehatan sebelum dan sesudah adanya dana desa. Namun yang menjadi faktor utama adalah jarak dan jenis jalan yang berbeda, di mana Desa Batu Layang dilintasi jalan nasional, sedangkan Desa Ujung Deleng adalah memiliki jalan yang kurang baik dan berada di pedalaman. Dengan perbedaan jalan menyebabkan perbedaan fasilitas pelayanan yang dirasakan. Namun, pemerintahan desa dapat menganggarkan banyak kegiatan kesehatan agar tetap berjalan dengan baik. Pemerintah desa juga dapat memperhatikan kader Posyandu dengan memberikan insentif.

Dana desa serupa juga dimanfaatkan desa dengan klasifikasi berkembang, yakni Desa Rambung Baru dan Desa Bandar Baru. Kedua desa tidak begitu sulit dalam hal pelayanan kesehatan. Hanya saja, Desa Rambung Baru untuk Poskesdes tenaga dokter tidak menetap dan hanya memantau saja. Ini dikarenakan tenaga dokter yang masih kurang dan di puskesmas dokter juga dibutuhkan. Apalagi puskesmas Sibolangit merupakan Puskesmas yang memberlakukan rawat inap dan IGD 24 jam. Pihak desa juga memberikan intensif kepada para kader Posyandu. Sedangkan, Desa dengan klasifikasi maju seperti Desa Suka Makmur. Dana desa yang ada dialokasikan untuk mendukung kesehatan pemerintahan desa dengan menganggarkan Insentif untuk kader Posyandu, PMT Lansia, dan PMT Balita.

Indokator Kedua yang menjadi penilaian Indek Desa Membangun adalah Pendidikan. Ada beberapa hal yang menjadi fokus penilaian; yakni akses pendidikan dasar dan menengah, akses pendidikan non formal, akses ke pengetahuan. Dalam prakteknya Dana Desa sangat membantu dalam pembangunan pendidikan di desa, termasuk infrastruktur dan kesejahteraan guru. Selain itu, pemerintah desa juga mampu meningkatkan kualitas mutu sekolah. Pembangunan akses menuju sekolah mampu mempersingkat jarak tempuh orang tua atau anak murid. Dalam angka 2019 ada 23 Lembaga PAUD, 21 SD, 7 SMP/sederajat, dan 2 SMA/sederajat di Kecamatan Sibolangit.

Pada desa dengan klasifikasi tertinggal, Desa Batu Layang dana desa digunakan dalam 
pembangunan jalan menuju sekolah. Dampaknya, timbul minat orang tua untuk menyekolahkan anaknya di PAUD dan SD yang ada. Pengalokasian dana untuk mengupayakan taman bacaan seperti perpustakaan yang ada dikantor desa. Untuk SMP dan SMA belum ada, sebab jarak ke Desa Bandar Baru cukup dekat sehingga anak-anak bersekolah disana. Sedangkan, Desa Ujung Ledeng Sekolah Dasar sudah ada, walaupun jumlah kelas tidak banyak. Untuk PAUD masih belum ada tempat, namun diupayakan pelaksanaannya dikantor desa. Perpustakaan di desa belum ada, sehingga tidak membuat taman bacaan. Selain itu, untuk SMP dan SMA desa juga belum ada.

Pada desa dengan klasifikasi berkembang dan maju, dana desa sangat membantu dalam pembangunan pendidikan di desa. Dalam hal ini perbaikan infrastruktur dan kesejahteraan guru. Selain itu, dengan adanya dana desa pemerintah desa mampu meningkatkan kualitas mutu sekolahnya. Sehingga orang tua murid mau menyekolahkan anaknya di desanya. Bahkan adanya pembangunan jalan ke sekolah mampu mempersingkat jarak tempuh orang tua atau anak murid ke sekolahnya.

Indikator ketiga adalah Modal Sosial, bisa juga disebut sebagai kontak sosial antar kelompok dan masyarakat. Dalam hal ini biasa dilakukan dalam bentuk tolong menolong, gotong-royong, toleransi, dan lain sebagainya yang berhubungan dengan kegiatan manusiawi (Hadi, 2000). Berdasarkan hasil wawancara, tingkat keamanan di desa masih dalam kategori yang cukup baik, karena kriminalitas masih sangat minim. Selain itu, untuk masyarakat yang kesejateraan sosialnya masih kurang, juga sangat rendah di desa-desa. Kemudian dalam hal bergotong royong dan toleransi umat serta etnis juga masih menjunjung tinggi. Namun, beberapa desadesa belum mempunyai sarana olahraga yang bisa dianggarkan dari dana desa. Banyaknya kebutuhan yang lebih pokok di desa, seperti pembangunan kantor desa, jambur, dan lain sebagainya.

Hal ini sejalan dengan yang disampiakan oleh Pendamping desa, di mana desa banyak menganggarkan pembuatan Poskamling dan biaya makan minum. Dana Desa lebih banyak digunakan untuk pembangunan. Untuk kesejahteraan sosial pemerintah desa mempunyai beberapa program, seperti PKH
(Program Keluarga Harapan) di mana setiap masyarakat yang kurang mampu mendapatkan bantuan. Dengan adanya program tersebut desa juga terbantu untuk pemberian anggaran kepada kesejahteraan sosial. Apalagi program Dana Desa tahun ini diprioritaskan untuk Pemberian Makanan Tambahan (PMT).

Indikator Keempat didimensi ketahanan sosial yakni pemukiman. Menurut UndangUndang Nomor 1 Tahun 2011 tentang Perumahan dan Kawasan Permukiman, Permukiman merupakam bagian dari lingkungan hunian yang terdiri lebih dari satu satuan perumahan yang mempunyai prasarana, sarana, utilitas umum, serta mempunyai penunjang kegiatan fungsi lain di kawasan perkotaan atau perdesaan. Melihat dari pengertian tersebut, dimensi ini memiliki hal yang menjadi penilaian yakni akses ke air bersih dan air minum, sanitasi, listrik, serta komunikasi dan informasi (Sirojuzilam, 2005).

Secara umum permukiman di desa-desa Kecamatan Sibolangit sudah cukup baik, seperti jaringan televisi dan internet sudah sangat baik. Walaupun dibeberapa desa masih sulit mendapatkan sinyal internet. Kemudian penganggaran tempat pembuangan sampah yang sifatnya sementara, membuat pemerintahan desa lebih banyak menganggarkan dari dana bagi hasil pajak. Ini dikarenakan dana yang dibutuhkan untuk pembangunan tidak begitu besar, sehingga tidak perlu menganggarkan dari dana desa. Bagi desa yang belum semua masyarakatnya memiliki MCK, desa menganggarkan untuk pembangunan MCK.

\section{Ketahanan Ekonomi}

Indeks Desa Membangun kedua yang jadi penilaian yakni ketahanan Ekonomi, ekonomi menjadi hal yang sangat penting bagi keberlangsungan perekonomian di desa dan pengembangan desa atau wilayah. Pembangunan tidak hanya soal ekonomi saja, dalam pengertian lain pembangunan harus mencakup masalah materi dan finansial dalam kehidupan manusia. maka pembangunan harus diselidiki sebagai suatu proses multidimensional yang mengikutsertakan reorganisasi dan reorientasi dari semua sistem ekonomi dan sosial (Todaro, 2000). Seperti diketahui ekonomi adalah ilmu yang mempelajari aktivitas manusia dan biasanya berhubungan dengan aktivitas produksi, jual- 
beli, konsumsi terhadap barang dan jasa, dan distribusi. Namun ekonomi juga memiliki artian yang sangat luas, keuangan di rumah tangga, perusahaan juga termasuk dalam ekonomi (Wasistiono, 2001).

Hasil penelitian mengenai ketahanan ekonomi di desa-desa Kecamatan Sibolangit, dana desa lebih banyak dianggarkan untuk pembangunan dan pembukaan jalan ke lahan pertanian. Hal ini dilakukan untuk pendistribusian hasil tani dari desa ke tempat pusat perekonomian. Apalagi masyarakat Sibolangit mayoritas berprofesi petani dan berkebun. Sehingga sangat perlu akses yang lancar untuk membawa hasil bumi tersebut. Selain itu, pembangunan infrastruktur dimaksudkan untuk menarik minat investor agar berinvestasi di desa. Hasilnya, beberapa desa di Kecamatan Sibolangit yang berhasil menarik minat investor dengan adanya akses jalan yang bagus. Dengan masuknya investor tentunya akan membuat perkembangan terhadap desa kea rah yang lebih baik.

Sibolangit selain dikenal dengan daerah pertanian, juga dikenal sebagai daerah wisata. Hal ini dapat dilihat dari banyaknya tempat wisata baik alam dan non alam. Tentu saja membawa dampak ekonomi tersendiri bagi masyarakat. Hal ini juga didukung dengan banyaknya hotel, restoran, dan kedai makan yang ada di Kecamatan Sibolangit. Keberadaan tempat wisata dan sarana pendukung lain, membuat perputaran keuangan menjadi lebih berkembang. Salah satunya munculnya lapangan pekerjaan bagi masyarakat dan usaha-usaha kecil lainnya. Ditambah lagi banyak koperasi yang berdiri, baik dari kelompok maupun individu, serta bank-bank swasta maupun negeri berdiri juga berpengaruh terhadap perekonomian di daerah ini.

\section{Ketahanan Ekologi}

Ekologi dapat dikatakan sebagai interaksi antar makhluk hidup dengan lingkungannya, menurut Kamus Besar Bahasa Indonesia ketahanan adalah kekuatan atau daya tahan. Sehingga penulis menyimpulkan ketahanan ekologi ialah daya tahan hubungan antara makhluk hidup dengan lingkungannya. Ketahanan ekologi memiliki subindikator yaitu kualitas lingkungan, dan potensi rawan bencana dan tanggap bencana (Tjahja, 2000).
Ketahanan ekologi di desa-desa Kecamatan Sibolangit sebenarnya tidak begitu rawan akan potensi bencana alam, sehingga Dana Desa tidak banyak dianggarkan pada ketahanan ekologi. Hanya saja masyarakat dan pemerintah desa tetap harus waspada, pernah terjadi bencana alam, seperti banjir di tempat wisata Desa Bandar Baru dan banjir bandang di Desa Martelu yang menyebabkan jalan penghubung desa terputus. Walaupun pada bencana alam ini tidak ada korban jiwa, namun terdapat kerugian materil. Selain itu, pihak desa juga selalu menghimbau warganya untuk selalu menjaga lingkungan seperti tidak menebang pohon sembarangan, sehingga dapat mengurangi bencana alam.

\section{Faktor Penghambat Desa}

Adanya Dana Desa tentu berdampak baik terhadap perkembangan desa, dengan dana yang telah dikucurkan membuat desa dapat membangun daerahnya. Namun, tetap ada persoalan yang dialami oleh desa dalam pengelolaan dana ini. Hal tersebut menjadi faktor penghambat utama dalam pengembangan desa. Faktor penghambat pengembangan desa, antara lain sumber daya manusia, swadaya masyarakat. Pengawasan masyarakat, partisipasi masyarakat dan perubahan anggaran (Miraza, 2005).

Sumber daya manusia menjadi hal yang sangat mendasar dalam pengelolaan dana desa, karena banyaknya tahapan dan proses membuat desa butuh sumber daya yang berkompeten. Proses pembuatan anggaran Dana Desa dilakukan dengan beberapa tahapan, mulai dari perencanaan, pelaksanaan, monitoring, dan evaluasi (Mangkuprawira, 2005). Kurangnya pengetahuan sumber daya manusia membuat beberapa desa di Kecamatan Sibolangit memakai jasa orang ke 3 dalam pembuatan RAB (rencana anggaran biaya). Hal ini lebih sering dilakukan dalam pembangunan, karena membutuhkan orang teknis yang mengerti sehingga dapat menyesuaikan dengan standar yang telah ditentukan oleh pihak kabupaten.

Berdasarkan hasil penelitian, sumber daya manusia yang ada di desa-desa masih perlu diberikan pelatihan-pelatihan mengenai pekerjaan yang akan dibuat. Kebanyakan hanya beberapa perangkat desa saja yang mampu bekerja dengan cukup baik, selebihnya masih belum mampu. Pengoperasian 
komputer atau laptop menjadi hal yang paling wajib untuk diketahui, terkhusus kepada perangkat desa yang bekerja dikantor desa. Hal ini berkaitan dengan proses suratmenyurat yang semuanya bermula dari desa. Untuk mendukung peningkatan kualitas sumber daya aparatur desa, hampir setiap tahun dianggarkan untuk pelaithan peningkatan aparatur desa.

Partisipasi masyarakat sangat dibutuhkan dalam memberi kontribusi dengan suka rela mulai dari proses perencanaan, sampai evaluasi dari program tersebut. Semakin tinggi tingkat partisipasi masyarakat terhadap sasaran suatu program, maka semakin tinggi tingkat keberhasilan dari program tersebut. Namun sebaliknya jika partisipasi masyarakat tidak maksimal dalam pengelolaan suatu program, maka tingkat keberhasilan kegiatan tersebut semakin rendah (Sulistiyani, 2009).

Partisipasi masyarakat dalam keberlangsungan dan pengelolaan Dana Desa di Kecamatan Sibolangit masih cukup rendah. Hanya beberapa desa saja yang tingkat partisipasinya cukup tinggi. seperti Desa Suka Makmur. Tingkat partisipasi masyarakat di desa ini dalam Musrebang desa cukup tinggi, dan dapat memakan waktu yang cukup lama dalam pelaksanaannya. Namun, di beberapa desa yang tingkat partisipasi masyarakat masih sangat rendah, juga ikut melaksanakan musrenbang ataupun rapat-rapat yang dinilai penting. Seperti yang diutarakan Camat Sibolangit:

"Memang partisipasi masyarakat dalam pembangunan desa masih sangat minim, seperti rapat musrenbang partisipasi masyarakat masih sangat rendah, padahal musrenbang merupakan rapat yang menentukan keberlangsungan pembangunan di desa kedepannya. Pemerintah kecamatan sampai harus memberikan persyaratan untuk memulai rapat wajib menghadirkan minimal peserta. Kenapa partisipasi masyarakat penting, karena apa yang diinginkan masyarakat akan ditampung dan diusulkan ke tingkat selanjutnya, dan musyawarah desa juga menentukan apa yang akan dibuat di desa tahun depan."

Dari pendapat Camat Sibolangit, dapat disimpulkan bahwa partisipasi masyarakat perlu ditingkatkan dalam hal pembangunan desa, sehingga setiap aspirasi dapat ditampung, sehingga nantinya masyarakat tidak protes dengan kebijakan yang telah dibuat oleh pemerintah desa. Apabila partisipasi masyarakat cukup tinggi, diharapkan tidak ada lagi anggapan aspirasinya tidak diterima. Bahkan dengan ikutnya masyarakat, tentu akan membuat pemerintah desa sulit untuk melakukan tindakan-tindakan yang dapat merugikan negara dan desa itu sendiri.

\section{SIMPULAN}

Peranan dana desa sangat mempengaruhi peningkatan Indeks Desa Membangun, melihat banyaknya dimensi dan indikator yang menjadi penunjang indeks desa membangun membuat dana desa tidak bisa dianggarkan ke setiap dimensinya, dan pemerintah desa serta masyarakat harus memilih yang mana menjadi prioritas. Ketahanan sosial, desa di kecamatan Sibolangit pada umumnya sudah sangat baik, walaupun masih ada beberapa desa yang belum tersentuh ketahanan sosial seperti perawat atau bidan yang belum bisa standby, sekolah yang belum memadai terkhusus tingkat menengah dan atas. Ketahanan ekonomi, di kecamatan Sibolangit masih belum merata walaupun hampir di setiap desa memiliki koperasi, namun perbankan, pusat perbelanjaan masih berpusat pada beberapa titik saja. Ketahanan ekologi, sebenarnya cukup baik, walaupun ada beberapa desa yang sudah mengalami bencana alam, seperti desa bandar baru dan desa Martelu. Namun, pada umumnya bencana alam yang dialami belum begitu mengkhawatirkan mengingat Sibolangit merupakan wilayah perbukitan. Faktor yang menghambat dana desa pada umumnya keterbatasan kemampuan masyarakat atau aparatur desa dalam mengikuti perkembangan teknologi, karena desa sudah banyak berasis teknologi, selain itu partisipasi masyarakat juga masih sangat kurang dalam keberadaan dana desa ini.

\section{DAFTAR PUSTAKA}

Astuty, E. (2013). Akuntabilitas Pemerintah Desa dalam Pengelolaan Anggaran Pendapatan dan Belanja Desa (Apbdes) (Studi Pada Alokasi Dana Desa Tahun Anggaran 2011 di Desa Sareng Kecamatan Geger Kabupaten Madiun). Publika, 1(2). Retrieved from https://jurnalmahasiswa.unesa.ac.id/index.p hp/publika/article/viewFile/2533/5599. 
Beni Haryanto Tambunan, Marlon Sihombing \& R. Hamdani Harahap, Peranan Dana Desa Dalam

Hadi, S.P. (2000). Aspek Sosial Amdal. Yogyakarta: Gadjah Mada University Press.

Hulu, Y. \& Harahap, R. \& Nasutian, M. (2018). Pengelolaan Dana Desa dalam Pemberdayaan Masyarakat Desa. Jupiis: Jurnal Pendidikan Ilmu-Ilmu Sosial. 10(1), 146-154. DOI: 10.24114/jupiis.v10i1.9974.

Idrus, M. (2009). Metode Penelitian Ilmu Sosial: Pendektan Kualitatif dan Kuantitatif. Jakarta: Erlangga.

Jamaluddin, Y. Sumaryana, A. Rusli, B. \& Buchari, R.A. (2018). Analisis Dampak Pengelolaan dan Penggunaan Dana Desa terhadap Pembangunan Daerah. JPPUMA: JPPUMA: Jurnal Ilmu Pemerintahan dan Sosial Politik UMA (Journal of Governance and Political UMA), 6 (1): 14-24.

Mangkuprawira, Tb. Sjafri. (2002). Manajemen Sumber Daya Manusia Strategik. Jakarta: Ghalia Indonesia.

Miraza, B.H. (2005). Perencanaan dan Pengembangan Wilayah. Bandung: Ikatan Sarjana Ekonomi Indonesia.

Pahlevi, I. (2015). Dana Desa dan Permasalahannya. Info Singkat P3DI. Retrieved from https://berkas.dpr.go.id/puslit/files/info_si ngkat/Info\%20Singkat-VII-17-I-P3DISeptember-2015-22.pdf.
Permendesa dan PDTTrans Nomor 2 Tahun 2016 tentang Indeks Desa Membangun.

Riyadi, M.M.D. (2000). Pembangunan Daerah Melalui Pengembangan Wilayah. Paper disampaikan pada Acara Diseminasi dan Diskusi Program-Program Pengembangan Wilayah dan Pengembangan Ekonomi Masyarakat di Daerah.

Sirojuzilam. (2005). Regional Planning and Development. Wahana Hijau: Jurnal Perencanaan dan Pengembangan Wilayah. $1(1)$.

Sulistiyani, A.T. (2009). Manajemen Sumber Daya Manusia: Konsep, Teori, dan Pengembangan dalam Konteks Organisasi Publik. Yogyakarta: Graha Ilmu.

Tjahja. S. (2000). Konsep Pembangunan yang Melakukan Pendekatan Kemanusiaan. Yogyakarta: Gadjah Mada University Press.

Todaro, M.P. (2000). Pembangunan Ekonomi di Dunia Ketiga. Jakarta: Erlangga.

Undang-Undang Nomor 1 Tahun 2011 tentang Perumahan dan Kawasan Permukiman.

Undang-Undang Nomor 5 Tahun 1979 tentang Pemerintahan Desa.

Undang-Undang Nomor 6 Tahun 2014 tentang Desa.

Wasistiono, S. (2001). Kapital Selekta Manajemen Pemerintahan Daerah. Jatinangor: Alqaprint. 